\title{
Medical Applications of Calciumphosphate Bioceramics
}

\author{
K. de GROOT \\ Biomaterials Research Group, School of Medicine, Leiden University, 2333 AA Leiden, The Netherlands
}

\section{リン酸カルシウム系バイオセラミックスの医学的応用 \\ K. de Groot}

Biomaterials Research Group, School of Medicine, Leiden University, 2333 AA Leiden, The Netherlands

\begin{abstract}
塊状アパタイト，金属基板に対するアパタイトや他種リン酸カルシウムのプラズマスプレーコーティングあるい はリン酸カルシウム粉末とポリ乳酸との複合体を作製する様々な方法について検討した．動物実験に拈いてこれ らのバイオセラミックスと骨との結合面は生体活性挙動によって特徵付けられ，すなわち骨はリン酸力ルシウム で被覆された移植物質の表面と結合することが判明した。塊状セラミックスは小さな, 荷重のかからない部分の 骨の置換や補強に適しており，一方プラズマスプレーした金属移植物質は表面の生体活性挙動及び移植物質自体 が充分な機械的強度を有することが臨床的に認められた.リン酸カルシウムセラミックスとポリ乳酸との複合体 は有望であるが，更により検討を要すると思われる．最近，我々の研究所で展開されたごとく，ヒドロキシアパ タイトコーティングは FDA 認可の股関節として用いられてきている.
\end{abstract}

[Received April 30, 1991]

\begin{abstract}
We discuss various methods to produce bulk apatites, plasmasprayed coatings of apatite and other calciumphosphates onto metallic substrates, and composites of calciumphosphate powders with polylactic acid. In animal studies it has been shown that the interfaces of these bioceramics with bone is characterized by a bioactive behaviour, meaning that bone bonds to surfaces of implants covered with calciumphosphate. Clinically, it has been found that bulk ceramics are suitable for small, unloaded implants to replace or augment bone, while plasmaspraying of metallic implants results in both bioactive behaviour of the surface and sufficient mechanical strength of the bulk of the implant. Composites of calciumphosphate ceramics and polylactic acid are promising and need further investigations. Currently, Hydroxylapatite (HA) coatings as developed by our laboratories are used in Food and Drug Administration (FDA) approved hip joints.
\end{abstract}

Key-words : Apatite, Bioceramics, Bone replacement, Interfacereactions, Plasmaspraying, Bioactivity, Biomaterials

\section{Introduction}

$\mathbf{S}$ URGICAL implants to repair or augment parts of the skeleton (bone, teeth, joints) can be produced from a number of materials, among which ceramics play an important role. There are two types of these specialty ceramics or bioceramics: bioactive ceramics and bioinert ones. Bioactive ceramics are all bioceramics that have at least a surface structure resembling that of the mineral phase of the skeleton, i.e. calciumphosphate. All other bioceramics (such as aluminumoxide) are bioinert.

Due to their similarity with (the mineral phase of) bone, bioactive ceramics bond to bone in a natural way. This property renders them very attractive for surgical application. Unfortunately, mechanically they are very weak, especially in tension, the consequence being that clinical application of bulk bioactive ceramics is limited to sites in the human body where no tensile forces are present. This is, for example, the case with middle ear ossicles.

Hence, in our laboratories we have not only developed methods to produce hydroxylapatite and related calcium phosphate bioceramics but also to increase surgical applications by strengthening these calcium phosphates by (1) applying them as a thin coating on metallic implants and (2) forming composites with suitable polymers.

Our goal is therefore :

- to be able to reproducibly apply bioactive calciumphosphate coatings on metallic substrates, such that joint replacement (hip, finger, knee) and tooth replacement, which are subjected to heavy loads, would be feasible;

- to produce bulk implants of calciumphosphates combined with polymers, leading to polymer composites.

2. Chemistry and physics of calcium phosphate ceramics $^{1)}$

The current knowledge of calcium phosphate bioceramics is best summarized in Figs. 1-4.

Figure 1 shows the possible phases of $\mathrm{CaO} / \mathrm{P}_{2} \mathrm{O}_{5}$ mixture. At temperature $T_{1}$ there exists the equilibrium for hydroxyapatite (HA): $\mathrm{Ca}_{10}\left(\mathrm{PO}_{4}\right)_{6}(\mathrm{OH})_{2}$ (or $\mathrm{Ap})=2 \mathrm{Ca}_{3}\left(\mathrm{PO}_{4}\right)_{2}\left(\right.$ or $\left.\mathrm{Ca}_{3} \mathrm{P}\right)+\mathrm{Ca}_{4} \mathrm{P}_{2} \mathrm{O}_{9}\left(\right.$ or $\left.\mathrm{Ca}_{4} \mathrm{P}\right)+$ $x_{1} \mathrm{H}_{2} \mathrm{O}$. Temperature $T_{2}$ separates the phase $\mathrm{HA}+\mathrm{CaO}$ from the phase $\mathrm{HA}+\mathrm{C}_{4} \mathrm{P}$. Temperatures $T_{1}$ and $T_{2}$ depend on partial water pressure, as Fig. 2 shows. 


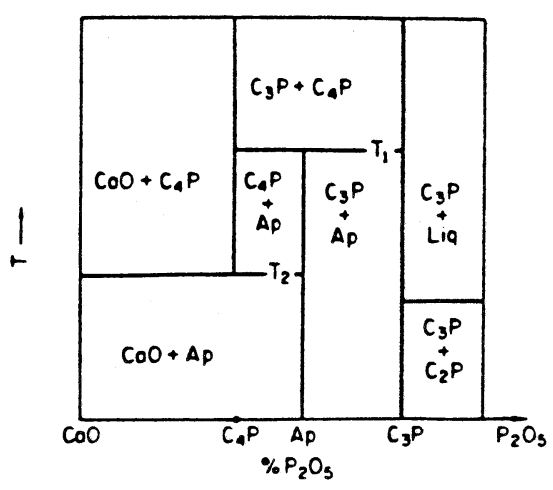

Fig. 1. Phase diagram of $\mathrm{CaO} / \mathrm{P}_{2} \mathrm{O}_{5}$ mixtures. Vertical axis: temperature: horizontal axis: percentage of $\mathrm{P}_{2} \mathrm{O}_{5}$ mixture. Ap: apatite (HA); C, P: component with the formula $(\mathrm{CaO})_{n}\left(\mathrm{P}_{2} \mathrm{O}_{5}\right)$, with $\mathrm{Ca} /$ $\mathrm{P}=n / 2$.

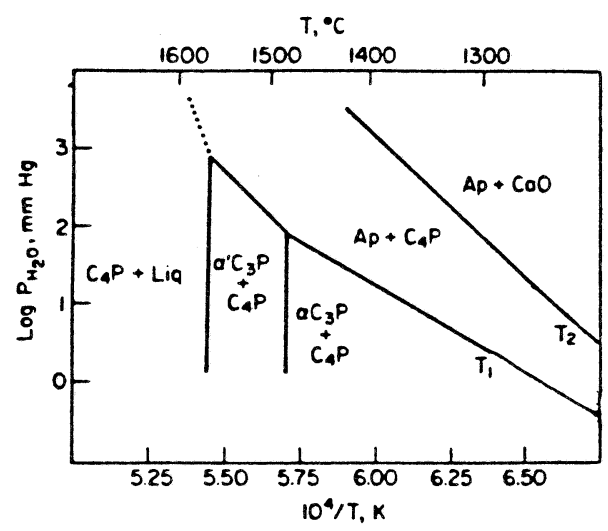

Fig. 2. Phase diagram of $\mathrm{CaO} / \mathrm{P}_{2} \mathrm{O}_{5}$ mixture showing the influence of water pressure. Vertical axis: $\log p_{\mathrm{H}_{2} \mathrm{O}}(\mathrm{mm} \mathrm{Hg})$; horizontal axis: $10^{4} / T$ ( $T$ in $\left.\mathrm{K}\right)$.

Figure 2 shows the influence of partial vapor pressure $\left(p_{\mathrm{H}_{2} \mathrm{O}}\right)$ on the stability of various calcium phosphates as a function of temperature. The temperature $T_{2}$ (see also Fig. 1), representing the equilibrium $\mathrm{HA}+\mathrm{CaO}=\mathrm{HA}+\mathrm{Ca}_{4} \mathrm{P}-\mathrm{H}_{2} \mathrm{O}$, decreases with increasing water pressure. The temperature $T_{1}$ (see also Fig. 1) shows that at a given temperature, for example $=1250^{\circ} \mathrm{C}$, a variety of coexisting phase may exist: if $\log p_{\mathrm{H}_{2} \mathrm{O}}(\mathrm{mm} \mathrm{Hg})<0$, the phases $\alpha \mathrm{C}_{3} \mathrm{P}+\mathrm{C}_{4}$ $\mathrm{P}$ are stable; if $0<\log p_{\mathrm{H}_{2} \mathrm{O}}(\mathrm{mm} \mathrm{Hg})<1$, the phases $\mathrm{HA}-\mathrm{C}_{4} \mathrm{P}$ are stable.

Figures 3 and 4 only differ in that the phases without water vapor (Fig. 3) are quite different from those with a vapor pressure (Fig. 4).

It is obvious that control over temperature, $\mathrm{Ca} / \mathrm{P}$ ratio and vapor pressure during sintering gives one the ability to produce a wide range of well-defined calcium phosphate products. Even more important : if these parameters are not all well defined a less well-defined end product may result.

Both the tensile strength and the compressive strength of a material depend on the portion of the total volume of the material occupied by interstices.

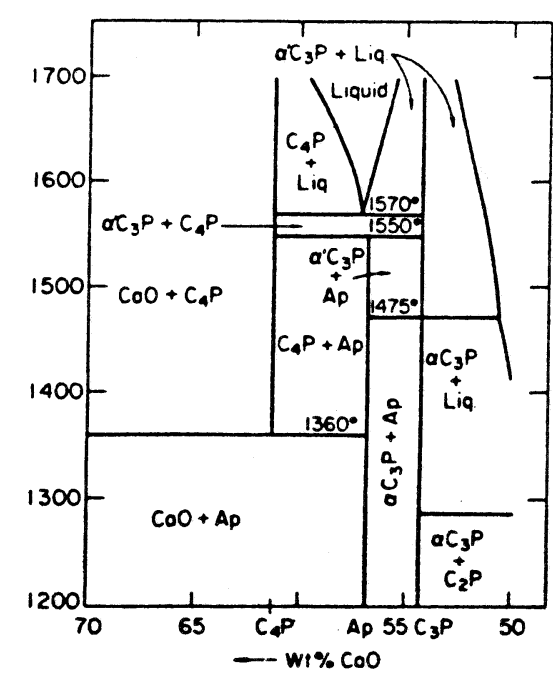

Fig. 3. Phase diagram of $\mathrm{CaO} / \mathrm{P}_{2} \mathrm{O}_{5}$ mixtures. Vertical axis: temperature on ${ }^{\circ} \mathrm{C}$; horizontal axis: $\mathrm{wt} \% \mathrm{CaO}$.

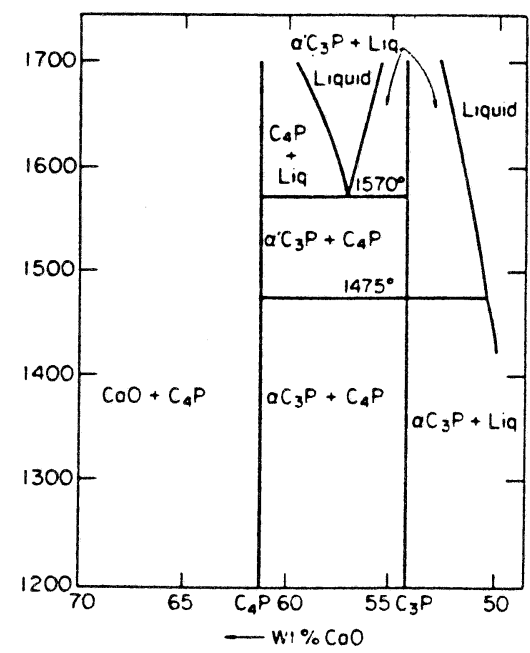

Fig. 4. Phase diagram of $\mathrm{CaO} / \mathrm{P}_{2} \mathrm{O}_{5}$ mixtures. Conditions identical to those in Fig. 3, except that the water pressure is $500 \mathrm{Hg}$.

These interstices or porosities are usually classified as comprising either micropores (having a diameter of several microns due to incomplete sintering of the particles) or macropores (having a diameter of several hundred microns thus allowing bony ingrowth).

In our laboratories we have found that the relationship between compressive strength $\left(\sigma_{\mathrm{c}}\right)$ and the portion of the total volume occupied by pores $\left(V_{\mathrm{p}}\right)$ may be described as expected for porous ceramics with a simple exponential equation.

$$
\sigma_{0}\left(V_{\mathrm{p}}\right)=700 \exp -5 V_{\mathrm{p}}(\mathrm{MPa})
$$

The equation describing the relationship between tensile strength $\left(\sigma_{\mathrm{t}}\right)$ and microporosity volume $\left(V_{\mathrm{mp}}\right)$ $\left(0<V_{\mathrm{mp}}<0.05\right)$ shows a large influence :

$$
\sigma_{\mathrm{t}}\left(V_{\mathrm{mp}}\right)=220 \exp -20 V_{\mathrm{mp}}(\mathrm{MPa})
$$




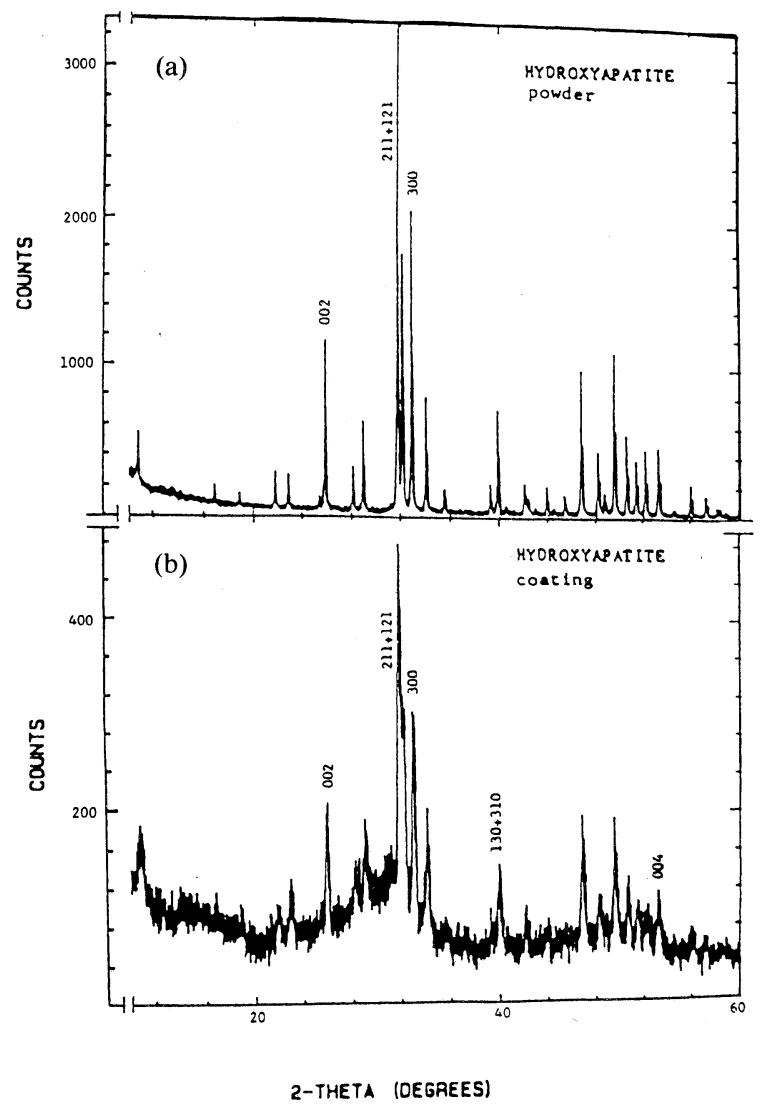

Fig. 5. X-ray diffraction pattern of HA. (a) Powder, (b) coating.

\section{Plasma-sprayed coatings of calcium phosphate}

Plasma spraying is a technique in which a DC electric arc is struck between two electrodes, while a stream of (mixed) gases passes through this arc. The arc turns these gases into an ionized mixture (a plasma) of high temperature and with a high speed of up to $1000 \mathrm{~km} / \mathrm{h}$. The temperature of the plasma rapidly decreases as a function of distance : within the arc, values of up to $20,000 \mathrm{~K}$ are reached, while $6 \mathrm{~cm}$ outside the electrodes, typical temperatures hover around $2000 \mathrm{~K}$ to $3000 \mathrm{~K}$. A powder, either metallic, ceramic, or even polymeric, suspended in a carrier gas, can be fed into the plasma and impinged in a (partially) molten or plastic state towards a surface. The surface, metal, ceramic, or even organic materials (such as paper), will then be coated with a layer of powder.

Plasma spraying is usually considered to be a "cold" process. Appropriate cooling techniques keep the temperature of the surface to be coated below $100^{\circ}$ to $150^{\circ} \mathrm{C}$, although the temperature of the particles may be much higher : a partially molten ceramic powder particle has an outside temperature of at least $1000^{\circ} \mathrm{C}$, depending on the ceramic, while a polymer particle still has a surface temperature of several hundred degrees centigrade.

In biomaterials research, plasma spraying has rapidly gained a distinct position; the first one to suggest a related spray technology was Hench, ${ }^{2)}$ who advocated the use of a flame spray (instead of a plasma an "ordinary" flame, produced by burning hydrogen or another gas in air) to cover metallic substrates with a "bioglass" layer. Unfortunately, at that time (the early 1970s) spray technology was not yet advanced enough to produce the high-quality coatings needed for medical implants. More recently, several research groups have, more or less independently, developed a reproducible method to obtain thin bioceramic coatings onto metallic and other substrates by means of plasma spraying.

Due to the very high temperatures of the plasma, the thermodynamical instability of calcium phosphate at such temperatures (as discussed in the previous paragraph) plays an important role. Ideally, only a thin outer layer of each powder particle gets into the molten plastic state which unavoidably undergoes phase transitions. This plastic state is necessary to ensure dense and adhesive coatings, but should comprise a negligible volume fraction of the calcium phosphate particle. By choosing an optimum relation between particle size (a molten larger of given thickness on a large particle occupies a smaller relative volume), type of gas (the heat content of a plasma, and thus the ability to increase the temperature of a particle, depends strongly on the gas used), speed of the plasma (the longer a particle resides in a plasma, the higher its temperature), and cooling process of the coated surface, one obtains coatings with the desired calcium phosphate $(\mathrm{s})$ and crystallinity. ${ }^{3)}$

The term "adhesion" has different meanings for different research communities. A simple description would be "the sticking together of two materials which may be similar or dissimilar". Adhesion can be described in terms of three categories : basic adhesion, thermodynamic adhesion (or reversible adhesion), and practical adhesion, referring respectively to atomic or molecular forces, to the thermodynamic work of adhesion, and to the measured force or work required to separate the two materials. The first two categories lend themselves to theoretical modelling, while the third category, also referred to as "bondstrength", is the subject of much experimental and practical work.

However, none of the present methods to test bond strength between metal (or other substrates) and ceramic coatings seems to have gained general acceptance. Failure of the bond is of a brittle nature and as such is strongly influenced by the maximum tensile stress across the ceramic-metal interface. It has been shown, by finite element analysis, that bond strength usually suffers from significant stress concentration effects. Since these effects are a function, of the various elasticity moduli, the testing method, shape of testing sample, and thickness of the brittle layer, bond strength measurements have only a rela- 
tive value.

For plasma-sprayed coatings, two methods are widely used :

(1) Scratch testing, in which a sharp needle under a given weight is being drawn with a certain force across the ceramic surface, the weight necessary to reach the underlying metallic surface being an indication of the "bond strength", which is only for comparison.

(2) Tensile and shear testing, in which, by means of a glue, a load normal and parallel, respectively, is applied to the ceramic coating, the loads expressed in force per area being called the tensile and shear strength, respectively.

HA coatings have only been subjected to the second test : tensile and shear strength determination. In our laboratory we have coated rods with a layer of $50 \mu \mathrm{m}$. For tensile strength measurement we coated the cross section (having an area of $0.95 \mathrm{~cm}^{2}$ ), and for shear strength, the cylindrical surface Araldite AV 118 glue was used to apply a force. For tensile bond strength the glue was put on the coated cross section and then subjected to a normal force (in tension). The values found were in the order of $70 \mathrm{MPa}$, and the failure mode occurred at the glue-apatite interface. The measured values therefore represent more the adhesive strength of the glue, rather than the bond strength of the coating. To measure bond strength in shear, the coated rod was potted into the glue and then pulled out of it. We found values of around $30 \mathrm{MPa}$ and, due to the fact that shearing results in wear attrition, it was not possible to determine the mode of failure, although usually more than half of the coating still seemed to be present.

An important aspect of ceramic plasma-sprayed coatings is their thickness : the mismatch in thermal properties coupled with the fast coating rate of the coating material during the plasma spray process gives rise to stresses in the coating and substrates; these stresses increase with the thickness of the coating. The compressive stress at the coating-substrate interface weakens the bond strength. Therefore, the thinner the coating, the higher its bond strength.4)

In addition, although rather trivial, it should be taken into account that the roughness of the coating is important if the main failure mode is at the glueceramic interface: increasing the roughness increases the contact area, and hence, the "apparent" bond strength.

We will discuss one other physicochemical aspect, namely the crystalline structure of coatings.5) We have shown that of three starting powders, $\beta$-TCP $\left(=\mathrm{C}_{3} \mathrm{P}\right), \mathrm{HA}$, and $\mathrm{TP}\left(=\mathrm{C}_{4} \mathrm{P}\right)$, coatings of about 50 $\mu \mathrm{m}$ can be easily produced. However the crystallinity of the coating always differs from that of the powders fed into the plasma flame : $\beta$-TCP turned completely into $\alpha$-TCP, HA showed an appreciable linebroadening of the peaks and TP changed only slightly after plasma spraying. Figures 5,6 , and 7 show

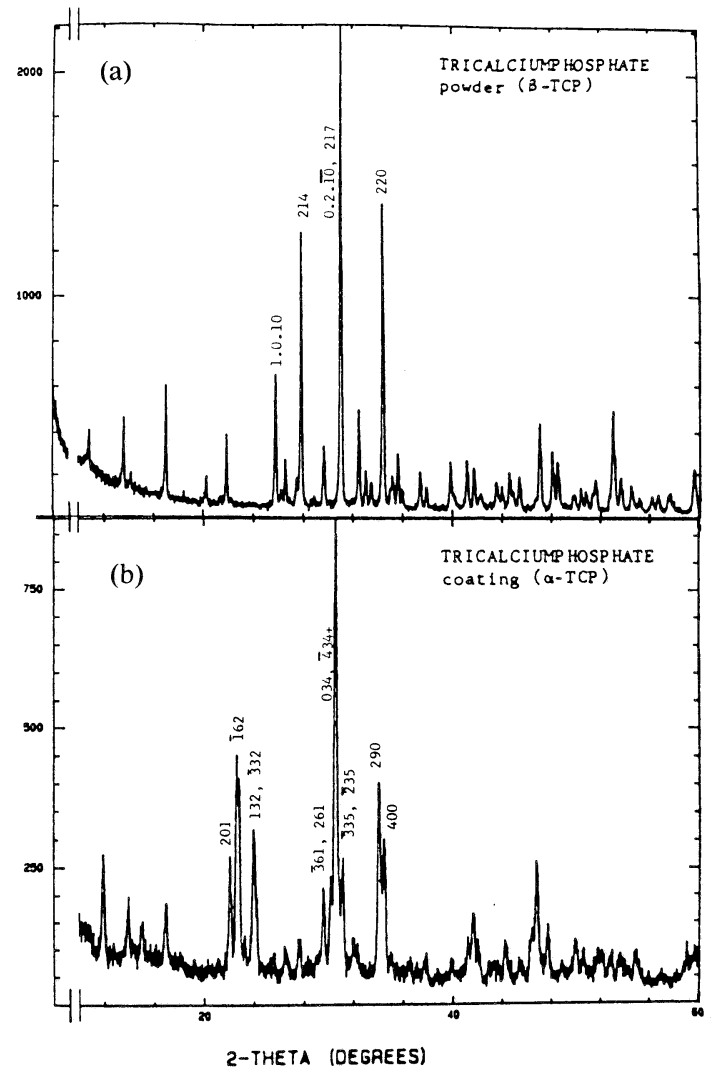

Fig. 6. X-ray diffraction pattern of tricalcium phosphate. (a) Powder with $\beta$-TCP, (b) coating with $\alpha$-TCP.

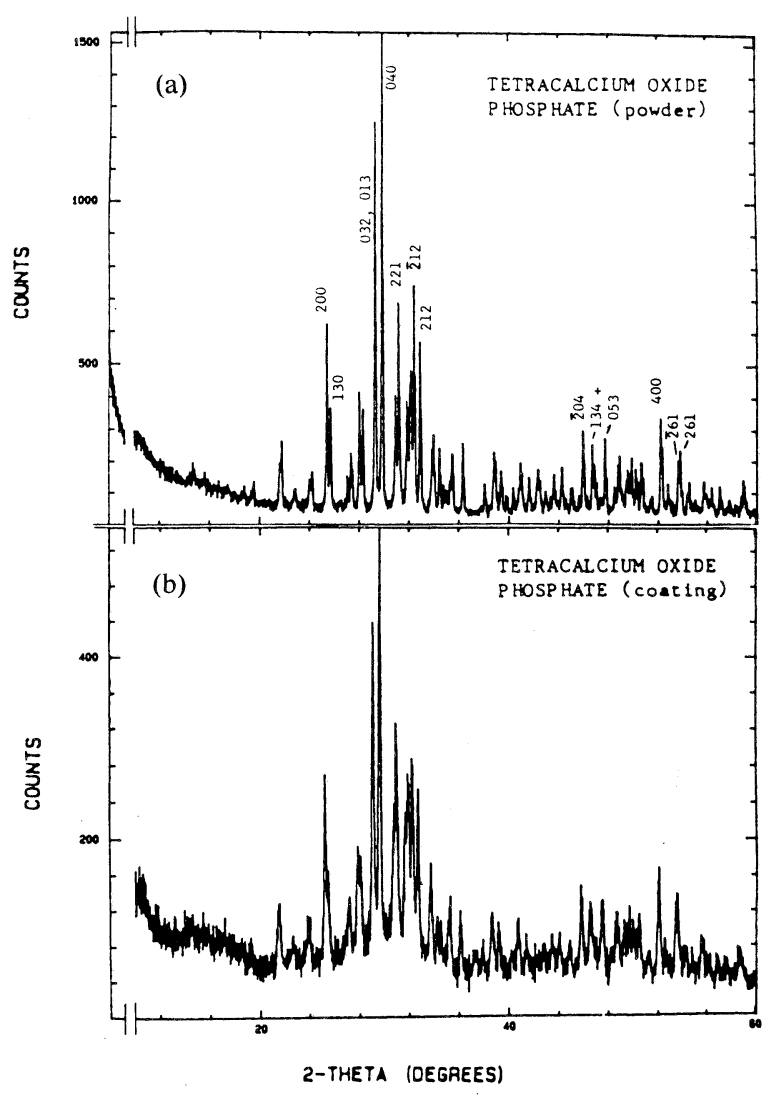

Fig. 7. X-ray diffraction pattern of tetracalcium monoxide diphosphate. (a) Powder, (b) coating. 
this clearly. These results are understandable in terms of the thermal stability : the transition temperature of $\beta$-TCP is around $1200^{\circ} \mathrm{C}, \mathrm{HA}$ decomposes at $1300^{\circ} \mathrm{C}$, and TP is stable above $1300^{\circ} \mathrm{C}$, and TP is stable above $1300^{\circ} \mathrm{C}$. Hence, the capacity of the plasma flame to induce phase transitions decreases in this order. One would expect that by preventing the $\beta$ TCP particles reaching a temperature which is higher than the transition temperature where $\alpha$-TCP is formed, the coating would be composed of $\beta$-TCP. Another method would be to heat the obtained $\alpha$ TCP coating to a temperature just below the transition temperature. As far as we know, these possibilities have not been tried experimentally. Similarly, it can be explained that heating $\mathrm{HA}$ coatings at $800^{\circ} \mathrm{C}$, for a few minutes, increases the crystallinity of the coating. Making use of the fact that at neutral $\mathrm{pH}$ and in aqueous solution, $\mathrm{HA}$ is the only stable phase, we obtained the same effect (increased crystallinity) by just storing a coating in such a solution for a few weeks at room temperature.

Several publications have appeared on the biological properties of HA coatings. Two aspects have been thoroughly discussed : reaction of surrounding tissue and "push-out" strength of coated plugs, both determined by implanting coated plugs into bone. Most studies have been performed on HA coatings. Although the general conclusions are similar, namely, that such a coating is a distinct improvement on the biocompatibility of (metallic) surfaces and that from a biological point of view, these coatings do act similarly to bulk surfaces of HA, there seems to be large difference with respect to the mechanical data.

One source of difference has been pointed out to be of experimental origin: Geesink ${ }^{6}$ ) showed that storing explanted plugs with surrounding (not trimmed) bone of formalin leads to an apparent push-out force twice as high as the same bone when tested freshly. Other differences in the literature are based on subsequent calculations:although the push-out force as measured by Thomas was similar to that in our tests, the subsequent transformation of this force into "stresses" led to a difference of a factor of 4 (30 MPa versus 6 to $8 \mathrm{MPa}){ }^{7}$ )

According to our earlier discussion one expects large variations in stress intensity along the bony interface, not only because of the inhomogeneous modulus of elasticity (for dense cortical bone, variations of a factor 2 are common), but also because of the fact that the ratio of thickness of bone vs. diameter of plug may vary for each implant.

Therefore, we believe it to be essentially incorrect to divide a push-out force through an area of cortical bone contact. A better method is to apply finite elemental analysis, and by doing so to calculate the maximum stress at failure, this maximum stress being a more true ultimate push-out strength.

Preliminary data suggest a difference between coated plugs and coated hip implants, at least for HA (other coatings have only been evaluated as implanted plugs for the relatively short time of 3 months), the difference being that on hip joints the coating partly disappears after 2 years of functional use in dogs. Since plug studies showed the coating to persist during 2 years, it seems that accelerated degradation may take place under loaded conditions.

Up to now, several thousands of HA-coated dental implants and at least 1000 coated hip implants have been applied in several selected clinical centers. ${ }^{8)} \mathrm{Un}$ til thus far reports have been positive. Both coated dental implants and artificial hip joints have been in use since 1986, which means that the bulk of the implants have been in use for probably less than 4 years.

Even though it is clear that applying a coating improves the biocompatibility of implants and that until now no negative side effects have been reported, a number of questions remain. First of all, what is the optimal thickness of a coating? We have already shown that a thicker coating is more brittle and less strong than a thin one. Since thinner coatings also adhere much better than thicker ones, it seems obvious that one should apply as thin a coating as possible : not only is it stronger, but it is also more adhesive.

However, the fact that even unloaded apatite surfaces degrade slowly places a lower limit to this initial assumption. Recent interpretations suggest that the main advantage of HA coatings is in the first year post implantation, which leads to the tentative conclusion that their use is essential for a limited period of not more than one year.

\section{Adhesion of other, non HA, calcium- phosphates to bone}

The purpose to this study was to compare, in a transcortical push-out model in goats, at 12 and 25 weeks, the interface behaviour of plasma sprayed fluorapatite (FA), magnesiumwhitlockite (MW), and hydroxylapatite (HA) coatings on Ti-6Al-4V titanium alloy implants, and grid-blasted noncoated Ti-6Al-4V titanium alloy implants (Ti). ${ }^{9)}$ As test we used the push-out method, in which plugs were implanted in bone, and pushed out after a certain implantation time.

The mean cortical thicknesses calculated after measuring each bone sample at for locations are shown in Table 1. The cortex of the humeri tended to be slightly thicker than that of the femora, but this was only significant for the 25 weeks group.

In Table 2 the mean push-out strengths \pm standard deviation are summarized for all implants in both follow-up periods.

The effect of the position (proximal to distal) of the implants on the push-out strengths was not significant, thus it was allowed to take account for other effects.

The effect of the position (proximal to distal) of the implants on the push-out strengths was not sig- 
Table 1. Mean cortical thicknesses $(\mathrm{mm}) \pm$ standard deviation as measured for the implants of each bone, for each follow-up period. *Indicates significant difference between femur and humerus at $p<0.05$.

\begin{tabular}{lcc}
\hline & 12 WEEKS & 25 WEEKS \\
\hline FEMUR & $2.86 \pm 0.78$ & $2.61 \pm 0.63^{*}$ \\
HUMERUS & $3.04 \pm 0.78$ & $3.00 \pm 0.83^{*}$ \\
\hline
\end{tabular}

Table 2. Mean push-out strengths $(\mathrm{MPa}) \pm$ standard deviation of the four different implant types after 12 and 25 weeks.

\begin{tabular}{llll}
\hline & 12 WEEKS & \multicolumn{2}{c}{25 WEEKS } \\
femur & humerus & femur & humerus \\
\hline $7.4 \pm 5.1$ & $6.7 \pm 2.0$ & $9.6 \pm 5.0$ & $7.5 \pm 3.9$ \\
$(n=7)$ & $(n=8)$ & $(n=7)$ & $(n=6)$ \\
$13.3 \pm 2.1$ & $11.1 \pm 5.2$ & $17.3 \pm 6.1$ & $13.3 \pm 6.0$ \\
$(n=8)$ & $(n=7)$ & $(n=8)$ & $(n=8)$ \\
$15.3 \pm 2.7$ & $10.4 \pm 3.5$ & $16.8 \pm 5.5$ & $12.1 \pm 2.0$ \\
$(n=8)$ & $(n=7)$ & $(n=7)$ & $(n=8)$ \\
$3.3 \pm 1.4$ & $3.4 \pm 1.5$ & $11.3 \pm 3.6$ & $8.5 \pm 2.6$ \\
$(n=8)$ & $(n=8)$ & $(n=7)$ & $(n=7)$ \\
\hline
\end{tabular}

Footnote : Ti : Titanium, HA : Hydroxylapatite coated Titanium, FA : Fluorapatite coated Titanium, MW : Magnesiumwhitlokite coated Titanium.

nificant, thus it was allowed to take account for other effects.

Firstly, the effect of the bone type (femur versus humerus) on the push-out data was calculated. For the 12 weeks follow-up, there was no single effect of the bone, but when coupled with the type of coating (coating by bone), this effect was significant. This means that there is an effect of the bone type on the push-out data, but this effect is dependent on the type of coating. Using $t$-tests, it was calculated that FA was responsible for this difference. On the contrary, for the 25 weeks follow-up, the effect of the bone separately was significant, but not when corrected for the type of coating. This means that the push-out strengths for the femora are higher than for the humeri, independent on the type of coating. The above mentioned results indicate that for both follow-up periods, further calculations have to be done for the two bone types separately.

All implants tended to have higher push-out strengths at 25 weeks. However, statistical testing of the findings using a $t$-test revealed only for the femoral MW implants a significant difference.

In Table 3, results from paired comparison testing are shown. For the femoral implants, at 12 weeks, both the HA and FA give significantly higher pushout values than the MW and Ti alloy implants. There exists no difference between FA and HA. In addition, the MW implants produced lower interfacial strengths than the Ti alloy implants. At 25 weeks, the results are similar, but the mean strength of the
Table 3. Results form the paired comparison testing. Mean differences in strength $(\mathrm{MPa})$ between the implant types, with their $p$-values, and after correction for the missing data by Analysis of Variance. $\Delta_{12}$ : difference at 12 weeks, and $\Delta_{25}$ : difference at 25 weeks, $\quad *: p<0.05 ; \quad{ }^{* *}: p<0.01 ; \quad{ }^{* * *}: p<0.005 ; \quad * * * *$ : $p<0.001$; n.s. : not significant.

\begin{tabular}{|c|c|c|c|}
\hline \multicolumn{2}{|c|}{ FEMUR. } & \multicolumn{2}{|c|}{ HUMERUS } \\
\hline$\Delta_{12}$ & $\Delta_{25}$ & $\Delta_{12}$ & $\Delta_{25}$ \\
\hline$-6.00^{* * *}$ & $-7.69^{x * *}$ & $-4.20^{*}$ & $-5.45^{*}$ \\
\hline$-7.97^{* * * *}$ & $-6.57^{*}$ & $-4.72^{* *}$ & $-4.28^{\text {n. s. }}$ \\
\hline$+4.01^{*}$ & $-1.90^{\text {n. s. }}$ & $+2.27^{\text {n. s. }}$ & $-1.79^{\text {n. s. }}$ \\
\hline$-1.97^{\text {n. s. }}$ & $+1.12^{\text {n. s. }}$ & $-0.51^{\text {n. s. }}$ & $+1.17^{\text {n. s. }}$ \\
\hline$+10.01^{\cdots *}$ & $+5.79^{\circ}$ & $+6.48^{* \cdots}$ & $+3.67^{\text {n. s. }}$ \\
\hline$+11.98^{x \times x}$ & $+4.67^{\text {n. s. }}$ & $+6.99^{\mathrm{xxx}}$ & $+2.49^{\text {n. s. }}$ \\
\hline
\end{tabular}

Footnote : Ti-HA means Titanium(uncoated) compared with Hydroxylapatite coated Titanium, Ti-FA the same but for Fluorapatite(FA), TiMW the same but for Manesiumwhitlockite, etc.

MW implants had increased and now only the HA implants showed significantly higher push-out strengths compared to the MW implants. With respect to the humeral implants, at 12 weeks again both the HA and FA implants had higher values than the $\mathrm{MW}$ and $\mathrm{Ti}$ alloy implants and there were no differences between both the FA and HA implants and between the MW and Ti alloy implants. At 25 weeks, only the HA implants and higher push-out values than the Ti implants, but the HA and FA implants, as well as the FA, MW, and Ti implants did not differ from each other.

The SEM pictures demonstrated that the FA coatings did not show signs of degradation for both follow-up periods. However, both the MW and HA coatings showed degradation. There was some coating visible, but this was not more than clusters of loose particles. This degradation was clearly visible at 12 weeks and showed further progress at 25 weeks. The fracture site for FA was in all cases the coatingtitanium interface, and in few samples also fractures inside the coating layer were visible. In the FA coated samples no fractures were seen at the coatingbone interface. For both HA and MW, the fractures were located at the titanium-tissue interface in the area were the coating had disappeared. On spots were the HA or MW coating still was visible, fractures were seen at the titanium-coating interface, within the (loose) coating particles, and at the coatingtissue interface. The fracture site at the Ti alloy implants was always at the titanium-tissue interface.

Thus, it was demonstrated that plasma-spraying of FA and $\mathrm{HA}$ results in a crystalline structure of the ceramic, as shown on the XRD-patterns. It was also shown that the FA coating showed a higher degree 
of crystallinity compared to the HA coating. These results are consistent with the findings of others. For $\mathrm{FA}$, the presence of FA-ions in the apatite crystal structure indeed enhances the thermostability of the material. Therefore, with respect to standardization and large-scale applicability of plasma-sprayed ceramics in implantology, the material characteristics of FA show advantages compared to HA. For MW, the phase transition of magnesium-bêta-whitlockite to magnesium-alpha-whitlockite after plasma-spraying, and the resulting amorphous/crystalline coating structure indicate a much lower stability.

Previously, we already stated that a wide range exists in measured push-out strengths for HA plasmasprayed coated plugs. Geesink ${ }^{8}$ showed in a Labrador dog study after 104 weeks a mean push-out strength of $29.7 \mathrm{MPa}$ for freshly excised samples. The cortical thickness was estimated at $1.75 \mathrm{~mm}$. Klein found, ${ }^{10)}$ in a Beagle dog study, after three months a mean push-out strength for $\mathrm{HA}$ of $34 \mathrm{MPa}$, and these samples were also tested fresh while the actual cortical thickness was measured. Cook ${ }^{7)}$ found in dogs after 10 and 32 weeks push-out strengths for HA-coated titanium of 7.3 and 6.1 respectively. Our findings for the HA- and FA-coatings are in the range between $10 \mathrm{MPa}$ and $17 \mathrm{MPa}$ at 12 and 25 weeks. It is obvious that there exist large differences between the results of the various groups. This variation can be due to differences in animal species, surgical techniques, implant dimensions, surface roughnesses, implant locations, fracture analysis, and of course the material characteristics. Due to this variability in test conditions, comparisons between the different centers is not possible and it is emphasized that comparing push-out results with each other is only allowed for in the same study, under exactly the same test circumstances.

The present investigation has demonstrated that (1) care has to be taken comparing bioactive materials in different bone types (femur versus humerus), (2) both FA and HA plasma-sprayed coatings give a firm fixation of an implant in cortical bone, compared to Ti alloy and MW implants, (3) FA does not and HA and MW do show degradation, (4) in FAcoatings, the push-out failure mode is at the coatingsubstrate interface, and (5) FA plasma-sprayed coatings have the potential to become an easy to standardize product for biomedical implant fixation.

\section{Hydroxylapatite/poly (L-lactide) composites}

The concept of rigid fixation of fractures by compression plating has been well established in orthopaedic surgery. No attempt is made, in this concept, to match the plate rigidity with the physiological needs of the skeletal system. Generally there is a mismatch between Young's modulus of cortical bone (7-30 GPa, depending on age, orientation and location) and the alloys commonly used for an internal fixation device (Titanium : $106 \mathrm{GPa}, 316 \mathrm{~L}-$ steel :
$200 \mathrm{GPa}$ ). The consequence may be that stress protection of the fracture site prevents the rapid proliferation of primary callus. The long term result in that case is a mechanically inferior bone structure in the region of the plate, because of osteoporosis and atrophy. ${ }^{11)}$

With this in mind, an improvement of a material for an internal fixation device would encompass mechanical properties that allow for sufficient support during the healing period and still permit healing by primary callus formation. Where bone healing is a dynamic processs such a material should be bioresorbable to insure a progressive stress transfer to the bone.

Several workers have tested materials that more or less meet these requirements. Poly (alfa-hydroxy acids) like poly(L-lactide) (PLLA), polyglycolide (PGA) and polydioxanone (PDS) are a group of materials which are under thorough investigation because of their biocompatibility, bioresorption and mechanical characteristics. These materials are successfully used as suture materials, as bone augments and for the fixation of fractures. Because metals are too stiff to prevent stress protection and polymers tend to be too flexible and too weak to meet the mechanical demands for an internal fixation device, composite materials should be considered for this purpose. Recently attention has been paid to the application of hydroxylapatite (HA) in combination with a polymeric substance. The use is still confined to the field to the filling of bony defects and as a drug carrier. Polyethylene, polybyturate and PLLA are the most frequently used polymers in such composite materials.

Synthetic HA is chemically as well as crystallographically closely related to the natural mineral component in bone. A major disadvantage is that it is brittle and has unfavourable mechanical properties where weight bearing is concerned. In contact with bone, synthetic HA has often been seen to develop a mechanically tight bond with bone which may be of a chemical nature. Synthetic HA is biocompatible and osteoconductive.

Adding HA, as a filler, to a (resorbable) polymer, which would stabilize the HA particles, is expected to increase the initial stiffness of the polymer without too much impact on the strength characteristics. Such a composite would resemble cortical bone which is a HA reinforced polymer (collagen) composite itself. Our interest is focused on a PLLA/HAcomposite material, combining bone bonding potentials (HA) with a considerable initial strength and stiffness, gradually losing its strength and resorbing (PLLA).

Hydroxylapatite powders were granulated and sintered for six hours at $1250^{\circ} \mathrm{C}$. Then the granules were crushed, milled and sieved to $<45 \mu \mathrm{m}$ particlesize. Appropriate weight by weight mixtures of dilactide and hydroxylapatite were heated to $150^{\circ} \mathrm{C}$ in 
rotating vacuum sealed ampoules for 72 hours. Stannous octoate was used to initiate these polymerizations. To obtain different molecular weights (MW) of the PLLA in the composites the polymerizations were carried out using three different Monomer (dilactide) to Initiator (stannous octoate) ratio's $(\mathrm{M} / \mathrm{I}=200,600$ and $2000 \mathrm{w} / \mathrm{w})$. At each ratio level 9 different weight percentages HA $(0-80 \%$ with $10 \%$ increment) were incorporated. Thus 27 composites were obtained.

To determine the molecular weight in the composites by viscosimetry, the materials were dissolved in chloroform and filtered to remove HA.

The second batch contained 9 materials : all combinations of PLLA with a M/I ratio of 200, 600 and 2000 and 0,30 and $50 \mathrm{wt} \%$ (approximately 15 and $25 \mathrm{vol} \%$ ) of HA. This resulted in various molecular weights as listed in Table 4. In order to study the influence of different particle sizes one more material was added to this sequence : $600 / 30$ with a HA particle size $<5 \mu \mathrm{m}(600 / 30 /<5)$. A $600 / 50 /<5$ composite turned out to be too brittle to be machined on a lathe.

In a pilot study certain mechanical characteristics of the first badge of 27 materials were assessed. Out of each of these materials 12 cylinders $(l=12 \mathrm{~mm}$, $d=6 \mathrm{~mm}$ ) were machined and tested for compressive- and diametral tensile-strength (according to Mitchell) on a HTE Houndsfield testing machine with a crosshead speed of $1 \mathrm{~mm} / \mathrm{min}$.

The 10 materials of the second batch were tested again for compressive- and tensile-strength and the $E$-modulus in compression was calculated. Additionally 6 rectangular specimens $(l=15 \mathrm{~mm}, w=10 \mathrm{~mm}$, $h=3 \mathrm{~mm}$ ) were tested on a $Z$ wick Dynstat apparatus (DIN 51230 ) for flexural strength in a 4-point bending test (DIN 53 452). The same specimens were used to measure the hardness number according to Vickers (Shimadzu micro-hardness tester, load: $200 \mathrm{gf}, 10 \mathrm{sec})$. Finally scanning electron micro- scopy on the fractured specimens and on the microindentation sites of the specimens was conducted.

After testing 27 composites in the range of $10-80$ wt $\% \mathrm{HA}$ for compressive and tensile strengths, 0, 30 and $50 \mathrm{wt} \% \mathrm{HA}$ were subjected to these and more mechanical tests. This choice was based on the fact that adding higher than $50 \mathrm{wt} \%$ HA to PLLA resulted in non coherent and chalky materials and adding lower than $20 \mathrm{wt} \%$ HA was presumed not to add significantly to the bioactivity or enhance mechanical properties.

The mechanical characteristics of the investigated materials are listed in Table 4. It was not possible to determine the diametral tensile strength of 2 unfilled PLLA materials because of their plastic behaviour.

In order to compare mechanical properties of different PLLA/HA ratios it is essential that the molecular weights of the examined materials are within a narrow range. A cross section of wt $\% \mathrm{HA}$ and $\mathrm{M} / \mathrm{I}$ ratio $(200 / 0,600 / 30$ and $2000 / 50)$ was taken with a molecular weight range of $125-150 \mathrm{kD}$.

Statistical analysis was carried out on the data. One way analysis of variance showed that there was a significant difference $(\phi<0.01)$ between the three mean values of each mechanical parameter. This result allowed for the testing of pairs by means of the unpaired $t$-test. This test revealed that all the differences are significant $(p<0.01)$ except for differences between 200/0-600/30 and 200/0-2000/50 pairs in flexural strength.

Comparing different particle sizes was done for the $600 / 30$ composite. The lower values were set as a percentage of the higher values.

Unpaired $t$-tests indicate higher strengths and $E$ modulus for the composite with the larger particle size $(p<0.01)$. Scanning electron microscopy was used to study the microstructure of the HA particles in the matrix and the polymer matrix itself at the fracture site and to look more closely at the micro-indentation. The fractured specimens of the unfilled

Table 4. Molecular weights and mechanical properties (mean \pm s.d.) of PLLA/HA composite materials.

\begin{tabular}{|c|c|c|c|c|c|c|}
\hline $\begin{array}{l}\text { Material } \\
\text { (M/l/wt\% HA) }\end{array}$ & $\begin{array}{l}\text { Mw } \\
\text { (D) }\end{array}$ & $\begin{array}{l}\mathrm{Sc} \\
(\mathrm{MPa})\end{array}$ & $\begin{array}{l}\mathrm{Ec} \\
(\mathrm{GPa})\end{array}$ & $\begin{array}{l}\text { St } \\
(\mathrm{MPa})\end{array}$ & $\begin{array}{l}\text { Sf } \\
(\mathrm{MPa})\end{array}$ & $\begin{array}{l}\mathrm{Hv} \\
\text { (gf/um2) }\end{array}$ \\
\hline $200 / 0$ & 130.000 & $125.5 \pm 8.3$ & $5.1 \pm 0.7$ & $21.8 \pm 4.5$ & $83.3 \pm 14.8$ & $28.4 \pm 1.2$ \\
\hline $200 / 30$ & 115.000 & $120.9 \pm 5.6$ & $5.1 \pm 0.9$ & $19.0 \pm 0.7$ & $44.3 \pm 12.2$ & $34.3 \pm 1.1$ \\
\hline $200 / 50$ & 65.000 & $99.4 \pm 2.0$ & $5.3 \pm 0.5$ & $14.0 \pm 1.1$ & $49.7 \pm 5.9$ & $33.7 \pm 1.0$ \\
\hline $600 / 0$ & 300.000 & $130.0 \pm 5.2$ & $5.2 \pm 0.7$ & $\star$ & $131.7 \pm 11.0$ & $28.5 \pm 2.1$ \\
\hline $600 / 30$ & 150.000 & $136.6 \pm 2.8$ & $6.8 \pm 0.3$ & $30.8 \pm 1.3$ & $93.0 \pm 2.8$ & $35.4 \pm 0.7$ \\
\hline $600 / 50$ & 100.000 & $86.6 \pm 3.9$ & $8.0 \pm 2.1$ & $11.3 \pm 1.4$ & $52.8 \pm 12.4$ & $32.4 \pm 0.9$ \\
\hline $2000 / 0$ & 450.000 & $122.4 \pm 3.9$ & $5.2 \pm 0.7$ & * & $146.0 \pm 25.4$ & $28.7 \pm 3.4$ \\
\hline $2000 / 30$ & 170.000 & $113.0 \pm 4.2$ & $5.4 \pm 0.9$ & $30.1 \pm 0.8$ & $101.5 \pm 5.0$ & $34.6 \pm 0.5$ \\
\hline $2000 / 50$ & 125.000 & $77.7 \pm 4.2$ & $6.2 \pm 0.3$ & $10.3 \pm 1.5$ & $74.7 \pm 8.1$ & $32.2 \pm 0.7$ \\
\hline $600 / 30 /<5$ & 100.000 & $107.1 \pm 4.3$ & $4.8 \pm 0.3$ & $21.4 \pm 1: 2$ & $59.6 \pm 1.9$ & $28.7 \pm 3.3$ \\
\hline $\begin{array}{l}\text { Mw: } \\
\text { Sc: } \quad \mathrm{C} \\
\text { Ec: } \quad M\end{array}$ & $\begin{array}{l}\text { olecular } \\
\text { ompressive } \\
\text { odulus of } \\
\text { ompression }\end{array}$ & $\begin{array}{l}\text { ght } \\
\text { trength } \\
\text { asticity }\end{array}$ & $\begin{array}{l}\text { St: Tensile } \\
\text { Sf: Flexur } \\
\text { Hv:Vickers } \\
\text { *: No fr }\end{array}$ & $\begin{array}{l}\text { strength } \\
\text { strength } \\
\text { hardness } \\
\text { ture }\end{array}$ & & \\
\hline
\end{tabular}


PLLA reveal a flaky, leaf shaped surface. The HA particles at the surface of the fracture site of composites seem to be loosely embedded in the polymer matrix with little or no adhesion. Furthermore the composite fractured through the polymer without cleaving the HA particles.

Equal $\mathrm{M} / \mathrm{I}$ ratios result in a variety of molecular weights in the $0,30,50 \mathrm{wt} \%$ HA range of the composite. In order to obtain materials with approximately the same molecular weights more monomer has to be added with higher wt\% HA in the composite. Apparently HA in some way affects the degree of polymerization. This effect on the MW of the resulting polymer is not fully understood but may be due to a synergistic effect of the HA on the initiator, making it more effective.

The mechanical tests of the materials tested in the cross section, with the similar MW's, showed an overall stronger, stiffer and harder $30 \mathrm{wt} \% \mathrm{HA}$ composite compared to the $50 \mathrm{wt} \%$ composite and the unfilled PLLA. Although the $30 \mathrm{wt} \%$ HA composite has the highest molecular weight $(150 \mathrm{kD})$ it is not likely that the noted differences in the mechanical tests are caused by the slight differences in molecular weights.

With respect to the particle size the $30 \mathrm{wt} \%$ composite with the larger particle size has favourable mechanical characteristics over the one with the smaller particle size. Scanning electron microscopy pictures give the impression that there is little or no adhesion between HA particles and the PLLA matrix. Smaller particles would increase the area of interaction which in this case is a disadvantage because the interaction seems to be limited or absent. Using smaller particles would therefore create merely more defects and consequently lower the mechanical properties of the composite.

In order to enhance mechanical properties of the composite efforts must therefore be made to improve the adhesion between matrix polymer and filler particles by the application of suitable coupling agents. Additionally, mechanical properties of hydroxylapatite reinforced poly(L-lactide) depend on parameters such as processing techniques, HA particle size and shape, PLLA molecular weight and PLLA/HA ratio. In this study the emphasis was on the PLLA/HA ratio. The other parameters have to be thoroughly investigated.

Within the range of the investigated MW's the PLLA $/ 30 \mathrm{wt} \%$ HA composite is a significant improvement of bulk PLLA. It combines bioresorption (PLLA) with bone bonding potentials (HA) resulting in a potentially bioactive and bioresorbable composite with higher strengths and stiffness than the unfilled polymer. The first results of the mechanical properties of the composite are promising and justify the in vitro and in vivo experiments which are currently conducted, studying biocompatibility, strength retention, bacterial adhesion, solubility and plug implantation.

As already discussed, it is possible to control the biodegradation rate to a certain extend by chain length. Longer chains degrade slower than shorter chains. In the near future therefore, we intend to evaluate this in quantitative terms for its composites with HA.

Furthermore, we have not yet optimalized particle size and shape of the HA-filler. According to the literature, in general these are parameters that might influence strength. Since the implants are degradable, we encounter the new situation that the strength of a degrading implants has to be controlled : optimally, one would like the strength decrease of the degrading implant to be compensated by the increase of strength due to bony replacement of the implant.

Therefore, we plan to study in animal models the strength of the implant-surrounding bone complex as function of implantation time, where we vary the parameters molecular weight of p-lactic acid, particle size and shape of HA filler.

\section{Clinical uses}

Table 5 presents the current clinical applications; Table 6 gives an overview of the current materials; and Table 7 presents the relationships among the current materials, their relevant properties, and their most relevant clinical applications.

Several remarks have to be made : (1) All the applications mentioned in Table 5 are limited to adult individuals. (2) The empty spaces in Table 6 suggest new $\mathrm{CaP}$ materials. (3) It is obvious that no distinction has been made between resorbability and nonresorbability in Table 7. Depending on the exact definitions of these terms, the applications may slightly vary, but it is undeniable that nonresorbable materials can be used for all the applications mentioned in Table 5. On the other hand, we believe that resorbable materials can only be used if they can be replaced by bone and if newly formed bony tissue does not eventually disappear. If these conditions must indeed be met, it would mean that resorbable materials could not be used for reconstruction of any congenital defect, for augmentation, as prosthetic implants, or as certain otology implants. Resorbable materials can be used for certain (noncongenital) reconstructions, namely, correction of periodontal defects, bone grafting, and cranioplasty. (4) In all applications (Table 5), interactions with soft tissue take place. Not much is known about these interactions, however, except for what has been learned in studies with hydroxyapatite (HA). But even with HA, sufficient information is only available for interactions with mucosal soft tissues (epithelium and connective tissue). Table 8 shows this lack of knowledge clearly. 
Table 5. Clinical applications for $\mathrm{CaP}$ bioceramics.

\begin{tabular}{lc}
\hline 1. Craniofacial Applications & 2. Prosthetic Implants \\
A. Augmentation & A. Subperiosteal implants (C) \\
Ridge (C) & B. Endosteal implants \\
Mandibular (C) & Endosseous implants (C) \\
Tygomatic (C) & Iindodontic pims (E) \\
Chin (C) & Orthodontic pins (E) \\
B. Reconstruction & C. Transosseous implants \\
Peridontal reconstruction (C) & Transmandibular implants (E) \\
Mandibular reconstruction (C) & \\
Orthognathy (C) & Bonegralting (C) \\
Cranioplasty (E) & 3. Otological Applications \\
Orbital lloor reconstruction (E) & A. Ossicular reconstruction (C) \\
Anterior nasal spine reconstruction (E) & B. Canal wall prosthesis (C) \\
\hline Nore: C: in current use, available to practicing dental surgeons. E: experimental, restrictive use.
\end{tabular}

Table 6. Classification of current $\mathrm{CaP}$ materials for head and neck applications.

\begin{tabular}{|c|c|c|c|}
\hline \multicolumn{4}{|c|}{ Material form } \\
\hline $\begin{array}{c}\text { Granule or } \\
\text { Paste }\end{array}$ & Solid & Coating" & $\begin{array}{c}\text { Rigid } \\
\text { Composite }\end{array}$ \\
\hline $\begin{array}{l}\text { Particles may be microporous. } \\
\text { macroporous (or both), or } \\
\text { coral porous; pastes may be } \\
\text { formed when collagen is } \\
\text { mixed with dense particles, } \\
\text { porous particles, or particles } \\
+ \text { BMP; pastes may also } \\
\text { be formed with CaHPO } \\
\text { particles }+\mathrm{CaSO}_{4} \text {, or } \\
\text { particles }+ \text { fibrin or } \\
\text { fibronectin }\end{array}$ & $\begin{array}{l}\text { Dense blocks ( } 5 \% \text { porosity); } \\
\text { coral solids (structured } \\
\text { porosity); macroporous } \\
\text { solids (random porosity) }\end{array}$ & $\begin{array}{l}\text { Sputtered, plasma-sprayed, } \\
\text { dipped-sintered, or } \\
\text { electrophoretic coatings }\end{array}$ & $\begin{array}{l}\text { PE-particle, PLA-particle. } \\
\text { PLA-porous solid, and } \\
\text { collagen-particle composites }\end{array}$ \\
\hline $\begin{array}{l}\text { Macroporous and dense } \\
\text { particles: pastes may be } \\
\text { formed with collagen mixed } \\
\text { with particles }\end{array}$ & Macroporous and dense & $\begin{array}{l}\text { Sputtered, plasma-sprayed, } \\
\text { and electrophoretic coatings }\end{array}$ & $\begin{array}{l}\text { PLA-particle and } \\
\text { collagen-particle composites }\end{array}$ \\
\hline Porous and dense particles & Porous and dense & Plasma-sprayed coatings & Collagen-particle composites \\
\hline Dense particles & Dense & & \\
\hline & Dense & & \\
\hline
\end{tabular}

NOTE : BMP : bone morphogenetic protein ; PE : polyethylene ; PLA : polylactic acid.

${ }^{a}$ Coating methods and coating thicknesses : sputtering $(1 \mu \mathrm{m})$, plasma spraying $(500-200 \mu \mathrm{m})$, dipping-sintering $(>100 \mu \mathrm{m})$, electrophoresis $(50-100 \mu \mathrm{m})$. Footnote : HA : Hydroxylapatite, TCP : Tricalciumphosphate, HA/TCP : mixture of Hydroxylapatite and Tricalciumphosphate, CaP glassceramics : calciumphosphate coating glassceramics, $\mathrm{CaP}$ materials : calciumphosphate coating materials.

Table 7. Clinical uses of $\mathrm{CaP}$ ceramics.

\begin{tabular}{|c|c|c|c|c|}
\hline & $\begin{array}{l}\text { Granule or } \\
\text { Paste }^{a}\end{array}$ & Solid $^{b}$ & Coating ${ }^{c}$ & $\begin{array}{c}\text { Rigid } \\
\text { Composite }^{d}\end{array}$ \\
\hline HA & $1 \mathrm{~A}, 1 \mathrm{~B}$ & $1 \mathrm{~A}, 1 \mathrm{~B}, 3 \mathrm{~A}, 3 \mathrm{~B}$ & $1 \mathrm{~B}, 2 \mathrm{~A}, 2 \mathrm{~B}$ & $1 \mathrm{~A}$ \\
\hline TCP & $1 \mathrm{~A}, 1 \mathrm{~B}$ & 1B & 2B & 1B \\
\hline HA/TCP & $1 \mathrm{~A}, 1 \mathrm{~B}$ & $1 \mathrm{~A}, 1 \mathrm{~B}$ & NR & NR \\
\hline $\begin{array}{l}\text { CaP-containing } \\
\text { bioactive glasses } \\
\text { or glass-ceramics }\end{array}$ & $1 \mathrm{~A}, 1 \mathrm{~B}$ & $1 \mathrm{~A}, 1 \mathrm{~B}, 3 \mathrm{~A}, 3 \mathrm{~B}$ & 2B & NR \\
\hline $\begin{array}{l}\mathrm{CaP} \text { materials with } \\
\text { ionic substituents } \\
\left(\mathrm{A} \mid \mathrm{CaP} \text { or } \mathrm{CaA} \mid \mathrm{PO}_{4}\right)\end{array}$ & $1 \mathrm{~A}$ & $1 \mathrm{~A}, 1 \mathrm{~B}$ & NR & NR \\
\hline
\end{tabular}

NOTE: See TABLE 5 to find what the code numbers above signify. NR: not reported.

${ }^{a}$ Properties: plasticity, malleability, ductility, low E, low porosity.

${ }^{h}$ Properties: good compression strength, poor fatigue behavior, high E, variable porosity (both micropores, which have diameters of a few microns, and macropores, which allow bony ingrowth and have diameters of at least 100 microns, are seen), low tensile strength.

'Properties: variable fatigue behavior (depends on thickness of coating), good compression strength, high $\mathrm{E}$, low porosity.

${ }^{d}$ Properties: variable E, variable porosity. 
Table 8. Biocompatibility of $\mathrm{CaP}$ ceramics with soft tissue.

\begin{tabular}{|c|c|c|c|c|}
\hline & Epithelial & Connective & Periosteal & Dermal \\
\hline HA & $Y$ & $Y$ & $\mathrm{Y}$ & Y \\
\hline TCP & $\mathrm{Y}$ & $?$ & $\mathrm{Y}$ & ? \\
\hline HA/TCP & $\mathrm{Y}$ & ? & ? & ? \\
\hline $\mathrm{CaP}$ glass-ceramics & $\mathrm{Y}$ & $?$ & ? & $?$ \\
\hline $\begin{array}{l}\mathrm{CaP} \text { materials with } \\
\text { ionic substituents } \\
\left(\mathrm{A} \mid \mathrm{CaP} \text { or } \mathrm{CaA} \mid \mathrm{PO}_{4}\right)\end{array}$ & $\mathrm{Y}$ & $?$ & $\mathrm{Y}$ & ? \\
\hline
\end{tabular}

NorE: Y: reports in the literature. ?: no reports in the literature.

\section{Summary of results}

With respect to apatite coatings, we have learned a number of important facts. First of all, contrary to our initial expectations apatite coatings are not biostable when implanted, but they degrade visibly within one year. Secondly, not less important, we showed that a coating is most important during the healing phase of the wound in which the implant is inserted. This means, that it is not necessary for a coating to be permanently present after wound healing and bony ingrowth has occurred.

We have completely characterized the coatings in terms of crystallographic structure, bonding strength, thickness, and in vitro and in vivo degradation behaviour. In addition the sequence of bone reaction towards such coatings has been delineated.Furthermore, we have critically evaluated so-called push-out strength measurement of the bone-implant interface, both from an experimental point of view as well with the aid of finite elemental analysis. Animal studies have confirmed, that the widely used "pushout" test results are not representative for the true tensile strength of a coating under in vivo conditions. Comparison of the adhesive strength of coatings before and after implantation showed a decrease from which it follows that biological interaction influences coating strength considerably. This biological effect was also shown by crystallographic changes taking place after implantation.
Most important, clinical results proved the coatings to enhance the performance of tooth implants and artificial hip joints dramatically.

It is expected that in the coming years throughout the world the majority of tooth-, hip-, and possibly other bony-implants will be coated with hydroxylapatite, or another calcium phosphate salt.

We have succeeded in producing composites of calciumphosphates and polymers, that are not only stronger than the original polymer but show a reaction with bone comparable with that of pure hydroxylapatite. As polymers we applied p-lactic acid which is biodegradable, and releasing innocent degradation products, thus being acceptable for implantation. Animal studies, conducted for polymercomposites, and additional tissue culture studies for p-lactic acid, have proven this. Hence, we expect to start with clinical studies soon.

\section{References}

1) K. de Groot, Ann. N. Y. Acad. Sci., 523, 227-33 (1988).

2) L. L. Hench, J. Biomed. Mater. Res. Symp., 7, 25-42 (1973).

3) K. de Groot, C. P. A. T. Klein, J. G. C. Wolke and J. M. A. de Blieck-Hogervorst, "Handbook of Bioactive Ceramics", Vol. II, Ed. Yamamuro et al., CRC Press (1990) pp. 133-42.

4) J. G. C. Wolke, W. J. A. Dhert and K. de Groot, Proceedings 7th CIMTEC, 1990, Faenza, Italy, accepted for publication.

5) B. Koch, J. G. C. Wolke and K. de Groot, J. Biomed. Mater. Res., 24, 655-67 (1990).

6) R. G. T. Geesink, Ph. D. Thesis, State University Limburg, The Netherlands (1988).

7) K. de Groot, J. Biomed. Mater, Res., 23, 1367-69 (1989).

8) R. G. T. Geesink, Clin. Orthop. Rel. Res., 261, 39-58 (1990).

9) W. J. A. Dhert, C. P. A. T. Klein, J. G. C. Wolke, E. A. vand der Velde, K. de Groot and P. M. Rozing, J. Biomed. Mater. Res., accepted for publication (1991).

10) C. P. A. T. Klein, P. Patka, H. B. M. van der Lubbe, J. G. C. Wolke and K. de Groot, J. Biomed. Mater. Res., 25, 53-65 (1991).

11) C. C. P. M. Verheyen, J. R. de Wijn, C. A. van Blitterswijk, P. M. Rozing and K. de Groot, submitted J. Biomed. Mater. Res. (1991).

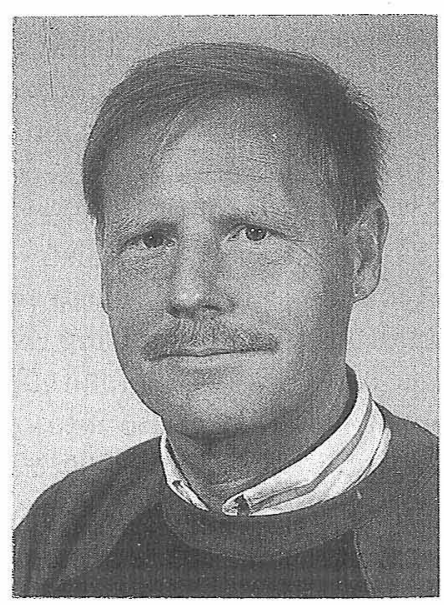

K. de GROOT, born on Nov. 3, 1940 in The Netherlands, has received his Ph. D. in physical chemistry at the University of Groningen (Netherlands) in 1968, after having spent two years as a research fellow at the University of North Carolina (1965-1967), sponsored by a Fulbright Fellowship. He started the Biomaterials Department at the Free University of Amsterdam in 1971, and moved to Leiden University (Netherlands) in 1988, founding there the Biomaterials Research Group Leiden, which he is currently chairing as Full Professor of Biomaterials.

Awards : George Winter Award, ESB (1985)

John Charnley Award (together with R. T. G. Geesink and C. P. A. T. Klein), American Hip Society (1987)

Visiting scientist : UCLA Bone Research Laboratory (1972)

Visiting professor : University of Utah, College of Engineering (1977) Beijing Medical University (1989 now) Sichuan Technical University (Chengdu) (1990-now)

Main interest in research : bioceramics (sintered calciumphosphate, composites, plasma-sprayed coatings, bioglasses) 